\title{
A replacement name for the Hispaniolan anole formerly referred to as Anolis chlorocyanus Duméril \& Bibron, 1837
}

\author{
Gunther Köhler ${ }^{1,2, *}$ (i) and S. Blair Hedges ${ }^{3}$ (D) \\ ${ }^{1}$ Senckenberg Forschungsinstitut und Naturmuseum, Senckenberganlage 25, 60325 Frankfurt a.M., Germany \\ ${ }^{2}$ Goethe-University, Institute for Ecology, Evolution \& Diversity, Biologicum, Building C, Max-von-Laue-Str. 13, 60438 Frankfurt am Main, Ger- \\ many \\ ${ }^{3}$ Center for Biodiversity, Temple University, SERC Building Suite 502, 1925 N 12th Street, Philadelphia, PA 19122, U.S.A. \\ *Corresponding author (gkoehler@senckenberg.de)
}

Article Registration: http://zoobank.org/urn:Isid:zoobank.org:pub:15CC1AAC-A134-42C5-966A-5D29B20A97A4.

Edited by: Robert Powell. Date of publication: 7 May 2020.

Citation: Köhler G, Hedges SB (2020) A replacement name for the Hispaniolan anole formerly referred to as Anolis chlorocyanus Duméril \& Bibron, 1837. Caribbean Herpetology, 70, 1-3.

DOI: https://doi.org/10.31611/ch.70

\begin{abstract}
We provide a replacement name, Anolis callainus sp. nov., for the Hispaniolan anole species formerly referred to as Anolis chlorocyanus Duméril \& Bibron, 1837. This is necessary because the syntypes of Anolis chlorocyanus Duméril \& Bibron, 1837 are conspecific with the only available syntype of Anolis coelestinus Cope, 1862. Thus, what was formerly known as $A$. coelestinus now must be referred to as $A$. chlorocyanus, and the A. chlorocyanus of former usage becomes $A$. callainus.
\end{abstract}

Keywords: Nomenclature, taxonomy, Reptilia, Squamata, Dactyloidae, Anolis chlorocyanus, Anolis coelestinus, Hispaniolan green anoles, Greater Antilles, Hispaniola.

In our revision of the green anoles of Hispaniola (Köhler \& Hedges 2016) we provided evidence that the six syntypes of Anolis chlorocyanus Duméril \& Bibron 1837 (MNHN-RA 0785, MNHN-RA 2007.2406, MNHN-RA 2007.2407, MNHN-RA 2007.2408, MNHN-RA 2007.2409, and MNHN-RA 0787) are conspecific with the only available syntype of A. coelestinus Cope, 1862 (i.e., MCZ 3347). We petitioned the International Commission of Zoological Nomenclature (ICZN) to use its plenary power to set aside the type status of the syntypes of Anolis chlorocyanus in order to stabilize the current and long established usage of the names A. chlorocyanus and A. coelestinus (Köhler \& Hedges, 2015). We also proposed that SMF 97845 should be the designated neotype of A. chlorocyanus Duméril \& Bibron 1837. However, with its ruling (a majority voted in favor, but not the required two-thirds majority), the commission did not approve our application (ICZN 2020). Therefore, Anolis coelestinus Cope, 1862 and Anolis chlorocyanus Duméril \& Bibron, 1837 are synonyms, and the latter name must be used for the species traditionally called Anolis coelestinus. We propose a replacement name for the Hispaniolan anole species formerly referred to as Anolis chlorocyanus Duméril \& Bibron 1837.

Anolis callainus sp. nov.

Anolis chloro-cyanus-Duméril \& Bibron 1837: 117; type locality: Martinique (in error) and "St.-Dominque," (=Hispaniola).

Anolis chlorocyanus—Boulenger 1885 (in part.), Garman 1887, Barbour 1914 (in part.), Schmidt 1921, Williams 1965 (in part.), Schwartz 1980 (in part.), Powell et al. 1996 (in part.), Köhler \& Hedges 2015, 2016.

Anolis chlorocyanus chlorocyanus - Schwartz \& Thomas 1975 (in part.), Schwartz \& Henderson 1988 (in part.), Schwartz \& Henderson 1991 (in part.), Ramos \& Powell 2001 (in part.), Henderson \& Powell 2009 (in part.). 
Holotype. Senckenberg Museum Frankfurt, SMF 97845, an adult male from El Limón, Samaná Peninsula (19.28929, -69.43118), 30 m, Samaná Province, Dominican Republic; collected 21 October 2013 by Gunther Köhler. Field tag number GK-4718.

Paratypes (n = 27). All from Samaná Province, Dominican Republic: MNHNSD 23.3604, SMF 97844, same collecting data as holotype. SMF 97846, Bahia Principe El Portillo, Samaná Peninsula (19.32417, -69.49523), 10 m, collected 23 October 2013 by Gunther Köhler. SMF 26060-61, Santa Bárbara de Samaná, collected 1939 by Robert Mertens. AMNH 42316, near Samaná, 1/4 mile on Sanchez Road, 2 mi out of Samaná, collected 15 October 1929 by William G. Hassler. AMNH 6055, 6061, 6063, 6067, 6146, 6200, Sanchez, collected 11 May 1915 by Clarence R. Halter. FMNH 5980 (1-10), Sanchez, collected 1924 by E. Kaempfer. KU 252203, Sanchez, collected 27 November 1971 by local collectors. KU 252350, 2 km E Las Terrenas, collected 21 August 1969 by J. R. Dennis. KU 252202, 5 mi NW Sanchez, collected 27 November 1971 by J. Acuna. KU 252351, Caba, collected 1 December 1971 by local collectors. FMNH 28240, Santa Bárbara de Samaná, collected August 1937 by W. J. Clench.

Diagnosis, description, and distribution: For a diagnosis, description, and distribution of $A$. callainus, as well as a detailed comparison with the other species of green anoles from Hispaniola, see Köhler \& Hedges (2016) (as A. chlorocyanus).

Etymology. The name callainus is Latin for pale green or blue-green and is used here as a masculine noun in apposition, referring to this species' overall coloration in life.

\section{Literature Cited}

Barbour T (1914) A contribution to the zoögeography of the West Indies, with special reference to amphibians and reptiles. Memoirs of the Museum of Comparative Zoology, 44, 209-359.

Boulenger GA (1885) Catalogue of the Lizards in the British Museum (Natural History). Second Edition. Vol. II. Taylor and Francis, London.

Duméril AMC, Bibron G (1837) Erpétologie Générale ou Histoire Naturelle Complete des Reptiles. Volume 4. Encyclopédique Roret, Librairie Paris, France.

Cope ED (1862) Contributions to Neotropical saurology. Proceedings of the Academy of Natural Sciences of Philadelphia, 1862, 176-188.

Garman S (1887) On West Indian reptiles. Iguanidae. Bulletin of the Essex Institute, 19, 25-53.

Henderson RW, Powell R (2009) Natural History of West Indian Reptiles and Amphibians. University Press of Florida, Gainesville, Florida.

ICZN (2020) Opinion 2449 (Case 3672) - Anolis chlorocyanus Duméril \& Bibron, 1837 and Anolis coelestinus Cope, 1862 (Reptilia, Squamata): conservation of usage of specific names by designation of a neotype for the former species not approved. Bulletin of Zoological Nomenclature, 77, 52-54.

Köhler, G, Hedges, SB (2015) Case 3672. Anolis chlorocyanus Duméril \& Bibron, 1837 and Anolis coelestinus Cope, 1862 (Reptilia, Squamata): proposed conservation of the specific names and designation of a neotype for A. chlorocyanus. Bulletin of Zoological Nomenclature, 72, 45-49.

Köhler, G, Hedges, SB (2016) A revision of the green anoles of Hispaniola with description of eight new species (Reptilia, Squamata, Dactyloidae). Novitates Caribaea, 9, 1-135.

Powell R, Henderson RW, Adler K, Dundee HA (1996) An annotated checklist of West Indian amphibians and reptiles, pages 51-93. In: Powell R, Henderson RW, editors, Contributions to West Indian Herpetology: A Tribute to Albert Schwartz (Society for the Study of Amphibians and Reptiles, Ithaca, New York).

Ramos YM, Powell R (2001) Anolis chlorocyanus Duméril and Bibron. Catalogue of American Amphibians and Reptiles, 728.1-728.6.

Schmidt KP (1921) Notes on the herpetology of Santo Domingo. Bulletin of the American Museum of Natural History, $44,7-20$. 
Schwartz A (1980) The herpetogeography of Hispaniola, West indies. Studies on the Fauna of Curacao and other Caribbean Islands, 61, 86-127.

Schwartz A, Henderson RW (1988) West Indian amphibians and reptiles: A check-list. Contributions in Biology and Geology Milwaukee Public Museum, 74, 1-264.

Schwartz A, Henderson RW (1991) Amphibians and Reptiles of the West Indies: Descriptions, Distributions, and Natural History. University of Florida Press, Gainesville, Florida, USA.

Schwartz A, Thomas R (1975) A checklist of West Indian amphibians and reptiles. Carnegie Museum of Natural History Special Publication, 1, 1-216.

Williams EE (1965) The species of Hispaniolan green anoles (Sauria, Iguanidae). Breviora, 227, 1-16. 